\title{
A Novel Isolate of Bacillus cereus Promotes Growth in Tomato and Inhibits Clavibacter michiganensis Infection under Greenhouse Conditions
}

\author{
Nallely Solano-Alvarez ${ }^{1}$, Juan Antonio Valencia-Hernández ${ }^{1}$, Enrique Rico-García ${ }^{1}$, Irineo Torres-Pacheco ${ }^{1}$, \\ Rosalía Virginia Ocampo-Velázquez ${ }^{1}$, Eleazar Máximo Escamilla-Silva ${ }^{2}$, Ana Luz Romero-García ${ }^{3}$, \\ Ángel G. Alpuche-Solís ${ }^{3}$ and Ramón Gerardo Guevara-González ${ }^{1, * \mathbb{D}}$
}

Citation: Solano-Alvarez, N.; Valencia-Hernández, J.A.;

Rico-García, E.; Torres-Pacheco, I.; Ocampo-Velázquez, R.V.;

Escamilla-Silva, E.M.; Romero-García,

A.L.; Alpuche-Solís, Á.G.;

Guevara-González, R.G. A Novel

Isolate of Bacillus cereus Promotes

Growth in Tomato and Inhibits

Clavibacter michiganensis Infection under Greenhouse Conditions. Plants 2021, 10, 506. https://doi.org/ $10.3390 /$ plants10030506

Academic Editor: Dariusz Latowski

Received: 6 February 2021

Accepted: 5 March 2021

Published: 9 March 2021

Publisher's Note: MDPI stays neutral with regard to jurisdictional claims in published maps and institutional affiliations.

Copyright: (c) 2021 by the authors. Licensee MDPI, Basel, Switzerland. This article is an open access article distributed under the terms and conditions of the Creative Commons Attribution (CC BY) license (https:// creativecommons.org/licenses/by/ $4.0 /)$.
1 C.A Ingeniería de Biosistemas, Facultad de Ingeniería, Campus Amazcala Universidad Autónoma de Querétaro, Carretera Chichimequillas s/n km1, El Marques, Querétaro 76265, Mexico; nallely.solanoa@gmail.com (N.S.-A.); qaantoniovalencia@hotmail.com (J.A.V.-H.); ricog@uaq.mx (E.R.-G.); irineo.torres@uaq.mx (I.T.-P.); rosov05@yahoo.com.mx (R.V.O.-V.)

2 Departamento de Ingeniería Quimica, Tecnologico Nacional de Mexico, Ave. Tecnologico y A. Garcia-Cubas, S/N, Celaya, Guanajuato 38010, Mexico; chiquisdrilis67@gmail.com

3 División de Biología Molecular, Instituto Potosino de Investigación Científica y Tecnológica, San Luis Potosi 78216, Mexico; rgggon@hotmail.com (A.L.R.-G.); alpuche@ipicyt.edu.mx (Á.G.A.-S.)

* Correspondence: ramon.guevara@uaq.mx

\begin{abstract}
The need to produce food in a sustainable way to counteract the effects of excessive use of agrochemicals opens the door to the generation of new technologies that are not based on fossil fuels and are less toxic to ecosystems. Plant growth-promoting bacteria (PGPB) could represent an alternative to chemical biofertilizers and pesticides offering protection for biotic and abiotic stresses. In this work, a bacterial isolate from roots of castor bean (Ricinus communis) was identified and named as Bacillus cereus strain "Amazcala" (B.c-A). This isolate displayed the ability to solubilize inorganic phosphate and produce gibberellic acid (GA3). Moreover, this bacterium provided significant increases in height, stem width, dry weight, and total chlorophyll content in tomato plants. Interestingly, B.c-A also significantly decreased the severity of bacterial canker disease on tomato caused by Clavibacter michiganensis $(\mathrm{Cmm})$ in preventive disease assays under greenhouse conditions. Based on our results, B.c-A can be considered as PGPB and a useful tool in Cmm disease control on tomato plant under greenhouse conditions.
\end{abstract}

Keywords: PGPB; bacterial canker; crop protection

\section{Introduction}

The rapid growth of the world population, as well as the need to produce food in a more sustainable way without the use of synthetic agrochemicals, has brought, in recent years, a search for alternatives substances [1]. One of these alternatives could be the use of beneficial microorganisms like plant growth-promoting bacteria (PGPB) that enhance plant growth involving direct mechanisms that improve nutrient uptake, regulation of phytohormones [2], and ability to cope with both biotic and abiotic stresses to which the plants are exposed [3].

PGPB's have the ability to directly stimulate the development of plants by means of several mechanisms such as nitrogen supply through the process of biological fixation of atmospheric nitrogen, production of growth-regulating substances, solubilization of minerals, induction of systemic resistance to pathogens, and inhibition of the growth of pathogenic organisms $[1,4]$.

The term PGPB includes three types of soil bacteria depending on their way of life: free-living bacteria that inhabit the area around the root (rhizosphere), those that colonize the root surface (rhizoplane), and endophytic bacteria that colonize inside the root [5]. This 
classification is not exclusive, since any individual bacterial strain can adopt any of the three lifestyles depending on the conditions of the soil environment and the root of the host involved [6].

There is evidence that many genera of bacteria can be a PGPB, for example Bacillus amyloliquefaciens, which confers protection in rice cultivation to stress caused by salinity and drought [7], Kosakonia radicincitans, which affects the number of amino acids, sugar and volatile compounds improving the flavor of the tomato [8], or even Variovorax paradoxus, which helps reduce fertilization in drought conditions of this same vegetable [9]. There also exist reports that the growth of tomato plants is enhanced by the inoculation of B. pumilus under additional $\mathrm{N}$ supply [10].

Tomato (Solanum lycopersicum) is one of the most cultivated vegetables worldwide over the last century [11]. In Mexico, tomato production in 2016 was more than 2.769 million tons, which makes it the main export crop growing at an annual rate of $6.5 \%$. The countries where tomato is mainly exported from Mexico are the United States, Canada, and Japan with a value of one billion USD, countries that have increasingly stricter regulations regarding the residuality of agrochemicals that are used in their production [11]. Bacterial canker of tomato caused by Clavibacter michiganensis ssp. michiganensis $(\mathrm{Cmm})$ is considered the most important bacterial disease affecting tomato crops worldwide [12]. This pathogen can enter the host plant through wounds and natural openings in leaves, stems and roots, and broken stomata [13].

In addition, $\mathrm{Cmm}$ can infect seeds externally, or it can enter seed coat and endosperm, and invade the xylem vessels, followed by a systemic infection of the host [13], when Cmm invades vascular tissues, initially causing wilting of leaves and leaflets, followed by wilting of the whole plant, necrosis, and cankers on the stems and petioles [14]. This infectious disease can spread rapidly and result in a severe loss of the productivity [15].

As for other bacterial diseases, currently there are not efficient chemical control strategies to cope with $\mathrm{Cmm}$ diseases [12]. Moreover, there are no tomato cultivars resistant to $\mathrm{Cmm}$ disease and breeding genetic progress for resistant lines is modest [16]. Hence, there is a need to generate technology according to the new demands of the market faced by producers, generating products based on PGPB's isolates where mainly these could confer some protection before the presence of the disease [17].

The present work aimed to evaluate the plant growth promotion and protecting effect against bacterial canker disease caused by $\mathrm{Cmm}$, of a novel isolate of Bacillus cereus strain Amazcala (B.c-A) isolated from roots of castor bean (Ricinus communis) on tomato plants under greenhouse conditions. Interestingly, B.c-A displayed biostimulant properties on tomato plants as well as protection against bacterial canker in vitro and in vivo under greenhouse conditions.

\section{Results}

\subsection{Isolation of Bacteria}

A soil sample was taken from the rhizosphere region of a castor bean plant, having reports of surviving different types of environmental stresses during at least 3 years in campus Amazcala of Autonomous University of Querétaro (Central México). From these samples, 5 types of colony morphologies were obtained, only one of them (named as isolate RR2) was selected for further studies in this work based on the higher appearance frequency in comparison to the other colonies. The morphology of RR2 colonies in Luria Bertani (LB) plates consisted in a circular shape and smooth appearance, irregular edge and creamy consistency, gram-positive bacilli, and identified as Bacillus cereus according to $16 \mathrm{~S}$ ribosomal gene DNA sequencing (96\% identity to B. cereus P0021 in BLASTn analysis). From herein, this bacterial isolate will be called B.c-A.

\subsection{Inorganic Phosphate Solubilization Tests}

B.c-A, displayed a transparent halo around the colonies grown in Pikovskaya medium in comparison with the control bacteria (a commercial product based on B. subtilis), thus 
indicating that this isolate is a phosphate solubilizer (Figure 1). This latter difference between the halos in both treatments resulted statistically significant according to Tukey test $(p=0.05)$.<smiles>[CH-]C</smiles>

Figure 1. Phosphates solubilization activity of B. cereus "Amazcala". As positive control of phosphate solubilization (Control, C), a Bacillus subtilis commercial strain with this property was used (see methods). Different letters in each bar indicates significant difference according to Tukey test $(p=0.05)$. The results are the average of two independent experiments $(n=3$, total in two experiments $n=6)$.

\subsection{Plant Growth Promotion in Tomato Plants}

After one month of weekly inoculations on tomato plants, no significant differences between the treatments with the two different concentrations of B.c-A were observed (Figure 2). However, both bacterial treatments were significantly different with respect to control without bacteria. Both treatments increased plant height, dry weight, stem width, and chlorophyll content (Figure 2). Thus, B.c-A showed significant growth promotion of tomato plants in both concentrations evaluated in the study. The fact that plant height was promoted by B.c-A in the tomato plants suggested the possibility that this microorganism produce gibberellins. Thus, a gibberellic acid (GA3) measurement test was carried out in B.c-A, showing that this bacterium was able to produce high levels of GA3 $\left(0.051 \mathrm{ng} \cdot \mathrm{mL}^{-1}\right.$, data not shown), likely suggesting that the phenotype of higher tomato plants was caused by the production of gibberellins.

\subsection{Enzymatic Plant Stress-Response}

B.c-A applications onto tomato plants displayed a significant increase in enzyme activities related to stress response and defense (Figure 3). The inoculation of the bacteria significantly increased enzyme activities related to ROS scavenging (Superoxide Dismutase, SOD and Catalase, CAT), as well as phenylpropanoids biosynthesis (Phenylalanine ammonia-lyase, PAL) (Figure 3). The increase in these enzyme activities suggested that B.c-A induced the innate immune system on tomato plants. The latter asseveration also suggested that it is likely that these treated plants might display increased tolerance to biotic stresses, based on the fact that the induction of these stress-response enzymatic systems is associated with increase in plant tolerance to diseases caused by several pathogens [17]. 

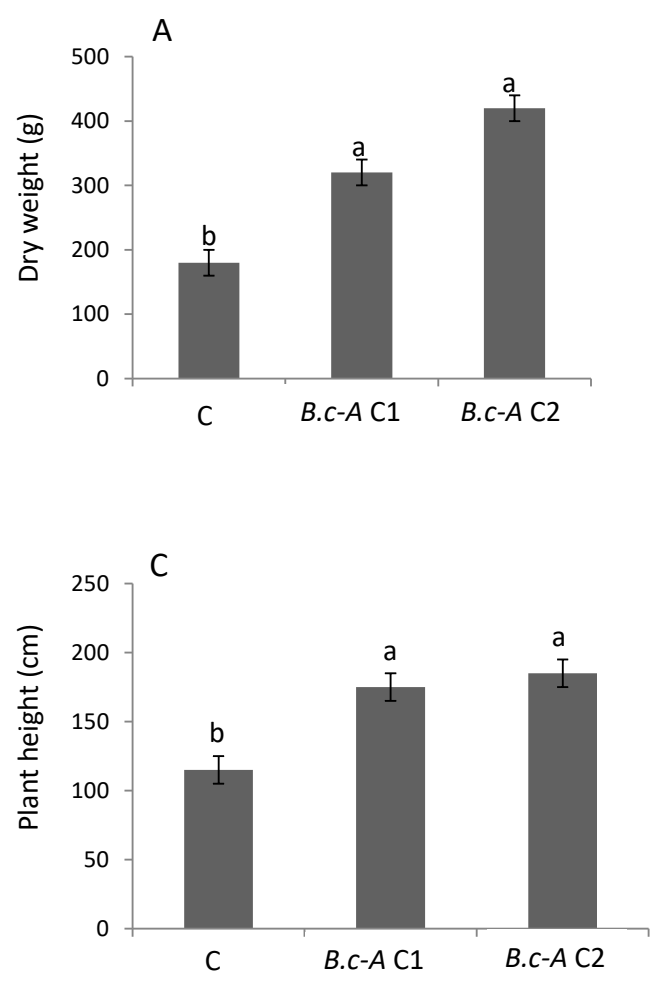

B
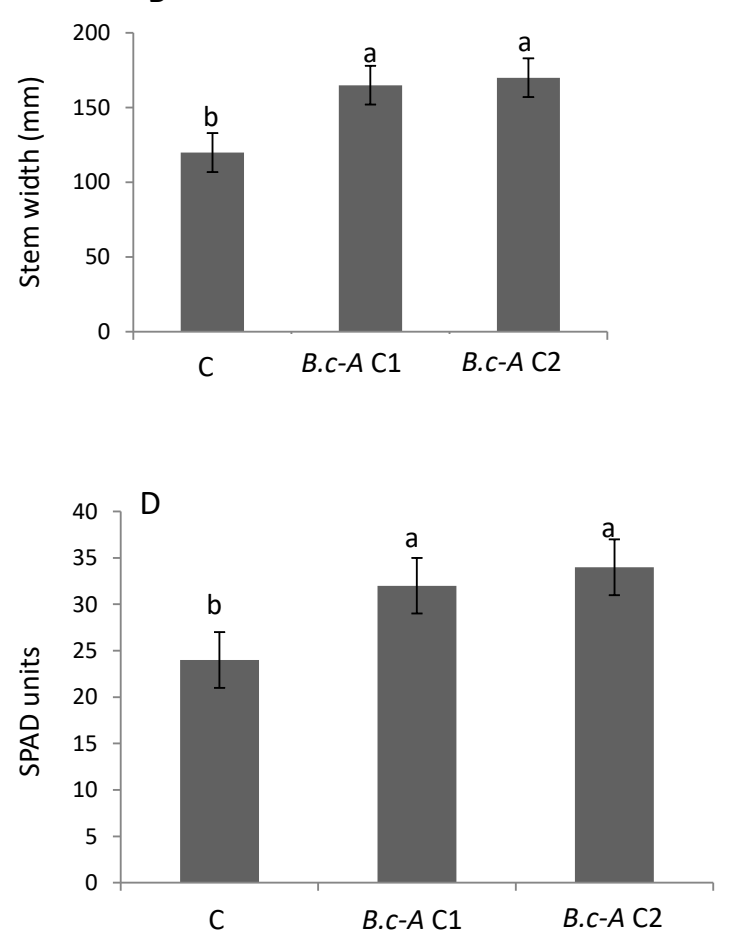

Figure 2. Effect of two colony-forming units (CFU) levels of B. cereus "Amazcala" on tomato performance. Panel A, Dry weight; Panel B, Stem width; Panel C, Plant height; Panel D, Chlorophyll levels as SPAD units. Simbology: C, control plants no-treated with B. cereus Amazcala; B.c-A, B. cereus Amazcala tested at $1 \times 10^{4} \mathrm{CFU} \mathrm{mL}^{-1}(\mathrm{C} 1)$ or at $1 \times 10^{8} \mathrm{CFU} \mathrm{mL}^{-1}(\mathrm{C} 2)$, respectively. Different letters in each bar for each panel indicates significant difference according to Tukey test $(p=0.05)$. The results are the average of two independent experiments ( $n=6$ for each experiment, total in two experiments $n=12)$.
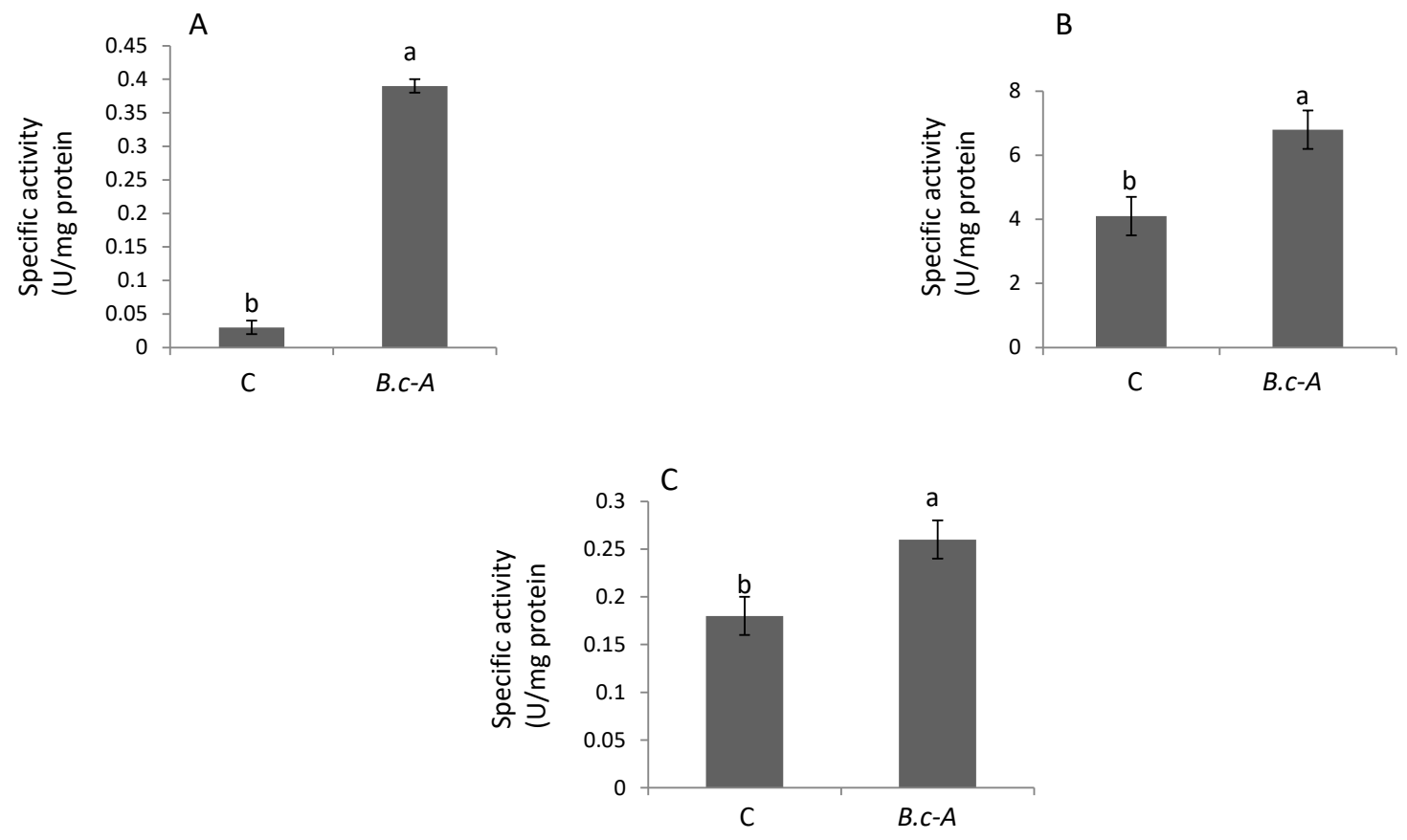

Figure 3. Stress-response enzyme activities in tomato plants treated with B. cereus "Amazcala". Panel A, superoxide dismutase (SOD); Panel B, catalase (CAT); Panel C, phenylalanine ammonia lyase (PAL). Simbology: C, Control plants mean plant non-treated with the bacterium; B.c-A, plants treated with B. cereus Amazcala. Different letters in each bar for each enzyme activity indicates significant difference according to Tukey test $(p=0.5)$. The results are the average of 2 independent experiments ( $n=3$, total in two experiments $n=6)$. 


\subsection{Gene Expression-Associated with Plant Defense}

In order to study, at a molecular level, the stress-response induced by B.c-A on tomato plants mentioned above, the expression of 2 genes related to plant defense was carried out. The chalcone synthase gene (chs) involved in phenylpropanoids biosynthesis (flavonoids) and the salicylic acid defense pathway gene marker pr1a were analyzed. On the one hand, the expression of chs was significantly induced by B.c-A (Figure 4). On the other hand, the relative gene expression of pr1a significantly decreased when tomato plants were treated with B.c-A in comparison with control plants (Figure 4).

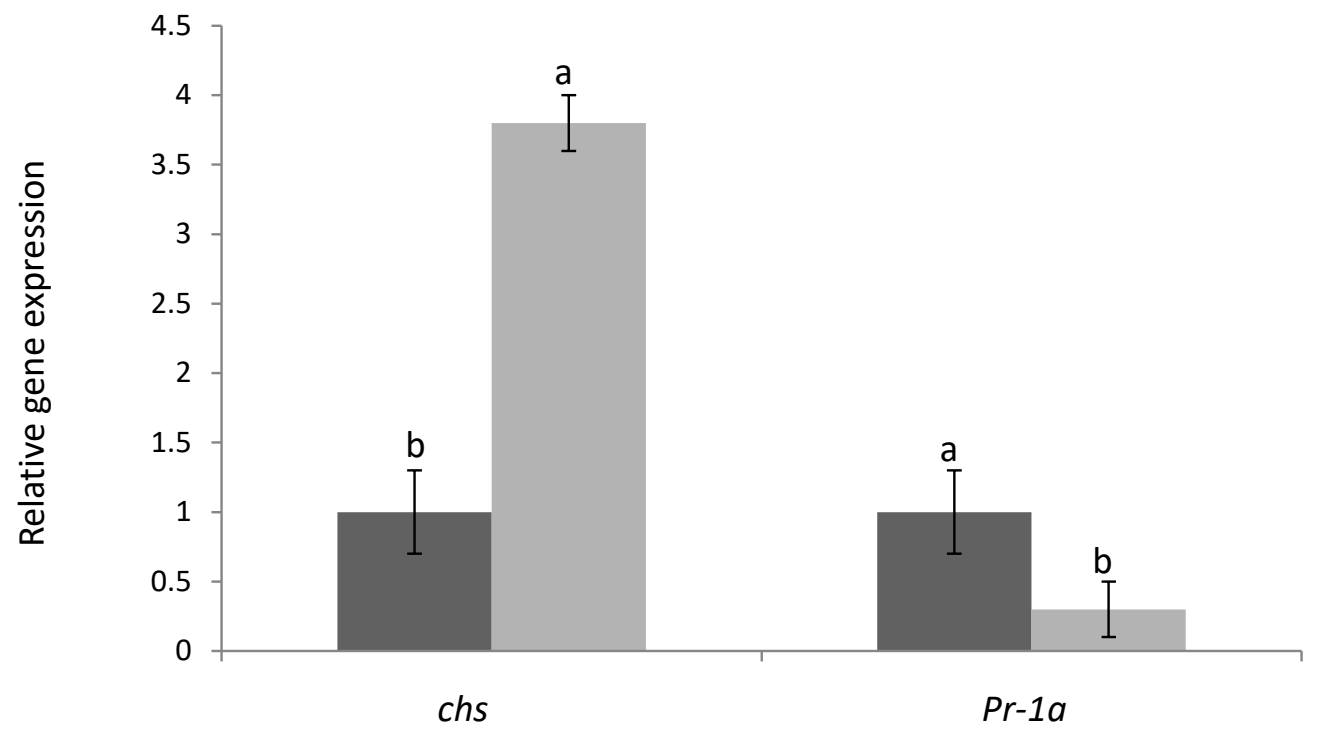

- Control

- B. cereus Amazcala

Figure 4. Relative gene expression of chalcone synthase (chs) and pathogenesis-related protein-1a ( $p r-1 a)$. Different letters in each bar indicates significant difference according to Tukey test $(p=0.05)$. The results are the average of two independent experiments $(n=3$, in total $n=6)$. Control plants mean plant non-treated with the bacterium.

\subsection{Antagonistic Activity of B.c-A against Cmm In Vitro}

The in vitro antagonistic activity of B.c-A against three different isolates of $\mathrm{Cmm}$ (sp, AcR42 and 1569) was evaluated (Figure 5). B.c-A displayed significant antagonistic activity against the 3 strains of $\mathrm{Cmm}$ evaluated (Figure 5). The supernatant of B.c-A grown in LB and MM evaluated in these tests displayed no significant differences in the antagonistic activity against the 3 strains of $\mathrm{Cmm}$ (Figure 5). In order to evaluate possible antagonistic effects of B.c-A on other types of bacteria, E. coli (DH5 $\alpha$ ) and an isolate of Pseudomonas aeruginosa were also included in these assays, showing no affection by B.c-A (data not shown).

\subsection{Activity of B.c-A against Tomato Bacterial Canker in Greenhouse Tests}

In order to evaluate the efficacy of B.c-A in protecting tomato plants against bacterial canker disease, two independent experiments were carried out under greenhouse conditions. For these studies $\mathrm{Cmm}$ AcR42, which is the most pathogenic isolate of the three evaluated in this work was used. The results displayed that plant size in control plants treated only with B.c-A was significantly the highest in comparison with the rest of the treatments (Figure 6, Panel A). This figure also shows that the treatment with B.c-A + Cmm AcR42 displayed significant higher plants than treatments only with Cmm AcR42 and those with $\mathrm{Cmm}$ + chemical product (Figure 6, Panel A). The severity of disease significantly decreased in approximately $50 \%$ with the application of B.c-A, and $25 \%$ with the chemical product in comparison control disease treatment (Figure 6, Panel B). Moreover, B.c-A even displayed significant decrease in severity level of disease in comparison with the chemical control (Figure 6, Panel B). The morphological aspect of B.c-A treated plants at 45 days post-germination displayed the beneficial effects of the bacterial treatments (Figure 7). 
A

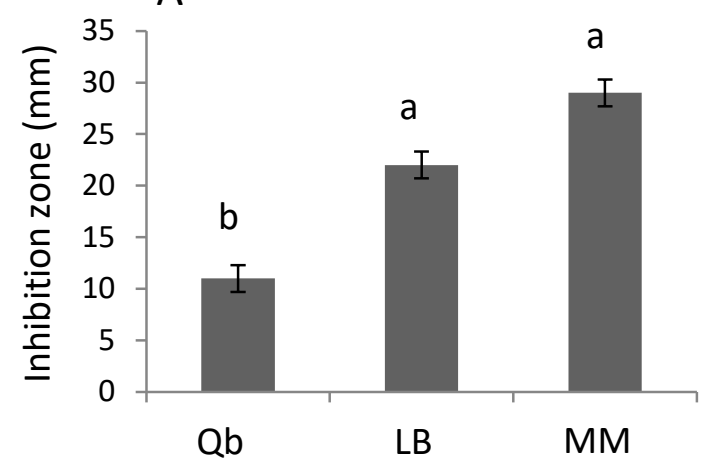

B

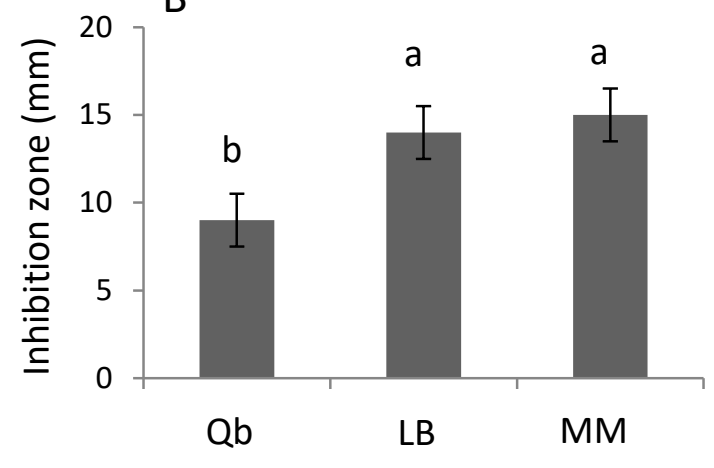

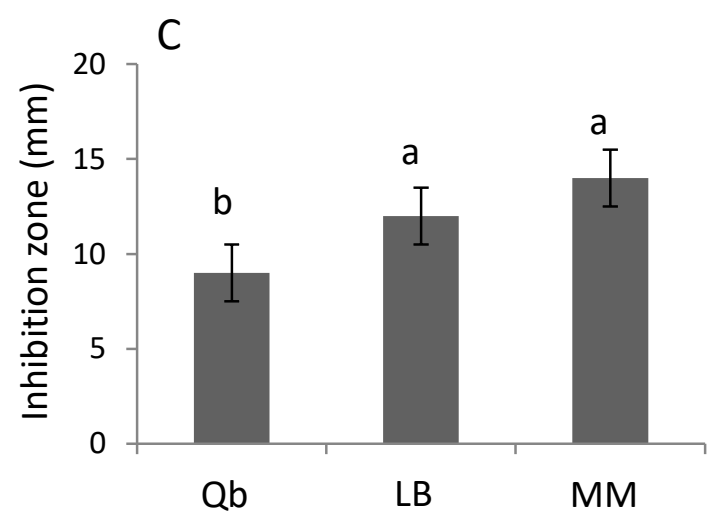

Figure 5. Size of the inhibition zone in the in vitro antagonistic tests of B. cereus Amazcala against 3 isolates of $C m m$. Panel A, against isolate sp; Panel B, against isolate AcR42; Panel C, against isolate 1565. B.c- $A$ was grown on Luria Bertani (LB) or minimal M9 medium (MM). As positive control against Cmm, a commercial product (Qbacter, Qb) was evaluated. Different letters in each bar for each panel indicates significant difference according to Tukey test $(p=0.05)$. The results are the average of three independent experiments ( $n=3$ for each experiment, total in three experiments $n=9)$.

A

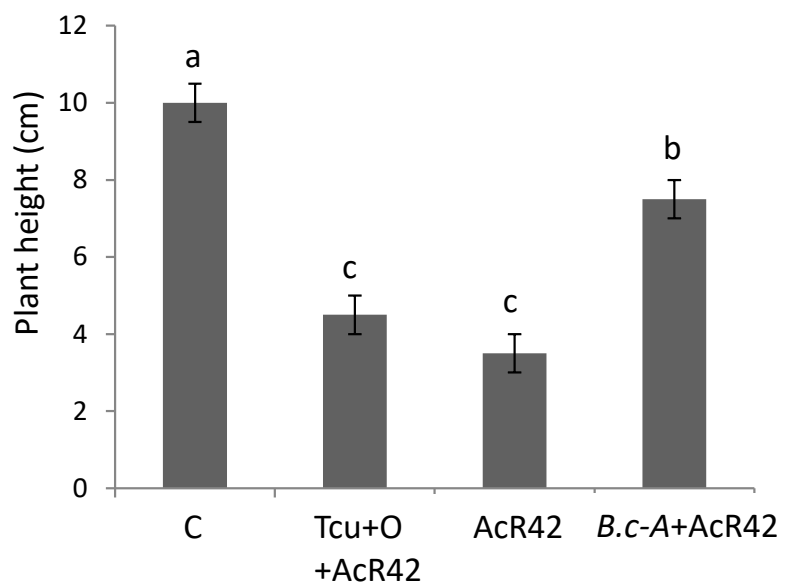

B

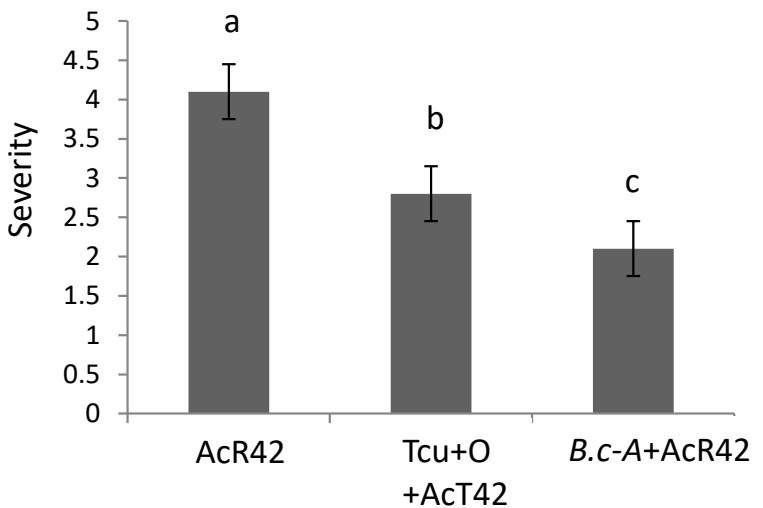

Figure 6. Plant height (Panel A) and severity (Panel B) of bacterial canker disease at 30 days post-inoculation in tomato plants treated with Cmm and/or B. cereus Amazcala under greenhouse conditions. As positive chemical control of bacterial canker, a commercial product (Terra-Cu-Oxymet) was evaluated. Control in panel A refers to plants inoculated only with B. cereus Amazcala. Simbology: C, Control; Tcu+O, Terra-Cu-Oxymet + Cmm AcR42; AcR42, Cmm isolate AcR42; Bc-A, B.cereus-Amazcala. Different letters in each bar indicate significant difference according to Tukey test in panel A, and Kruskal-Wallis $\mathrm{H}$ test in panel $\mathrm{B}$, using in both tests a significance of $p=0.05$. The results are the average of 2 independent experiments ( $n=9$ for each experiment, total in two experiments $n=18$ ). 
B. cereus

C (-)

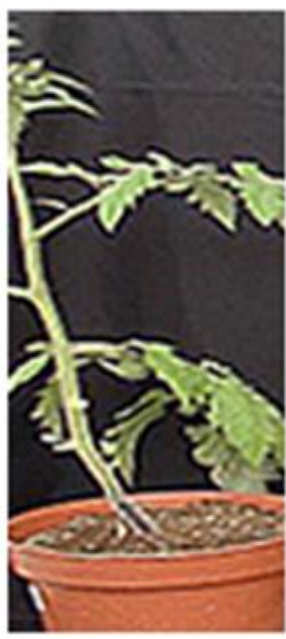

Amazcala $+\mathrm{Cmm}$

AcR42

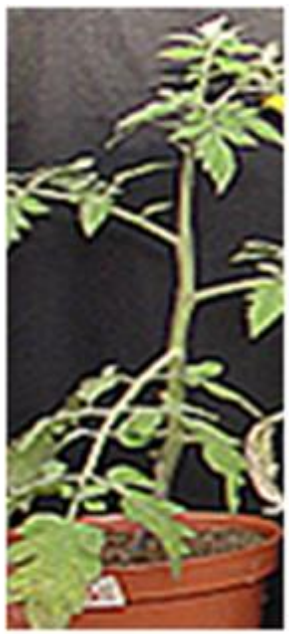

B. cereus

Amazcala

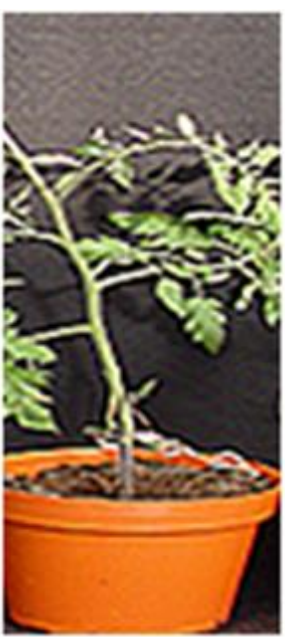

Cmm AcR42

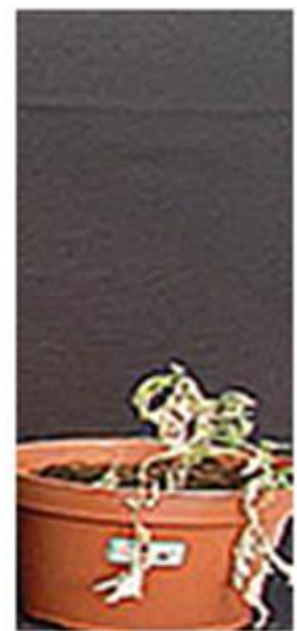

Figure 7. Typical symptoms of the tomato plants preventively treated with B. cereus Amazcala and infected with $\mathrm{Cmm}$ AcR42. C (-), negative control treated neither with B. cereus Amazcala nor Cmm Ac42; Cmm AcR42, plant treated only with phytopathogenic Cmm AcR42.

\section{Discussion}

The deficiency of phosphorus $(\mathrm{P})$ in the soil influences the delay in maturity in the development of the plants, decreasing the yield of the harvest [18]. The Pikovskaya medium contains tricalcium phosphate, which is an inorganic poor soluble source of $\mathrm{P}$ and is not assimilable by the plant. However, a transparent halo formed around a bacterial colony indicates capacity of dissolving this inorganic salt, thus becoming an assimilable form. As shown, B.c-A, was able to produce halo in Pikovskaya medium, indicating that this isolate possesses the capacity to solubilize $P$ from unavailable sources. This activity has been reported in several Bacillus species, including B. cereus, mediated by producing several organic acids as lactic, acetic, and gluconic acids [19]. Future studies with P-solubilizing activity of B.c-A will consider the use of harder-to-dissolve compounds, such as Fe-P or Al-P in order to establish, in a more robust way, the phosphorus solubilization capacity of B.c-A [20].

Several authors have reported that Bacillus species (including $B$. cereus) are active producers of several gibberellins, significantly increasing plant height in pepper plants [21]. B.c-A displayed plant growth promotion activity on the variety of tomato evaluated in this study, suggesting the possibility that this isolate is a producer of gibberellins that in fact were tested in the present work. As mentioned in the results section, this isolate produced high amounts of GA3 in culture medium. This gibberellic acid production activity might also be found when testing these bacteria in different plant species from the one they were isolated (as is the case of B.c-A that was isolated from castor bean but improved performance in tomato). The PGPB activity of several microorganisms on different crops with a specific bacterial genus has already been reported in grasses, fabaceae, and some weeds $[2,22,23]$.

Earlier literature suggested that in most of the cases, PGPBs trigger defense-responses, leading to the production of biochemical and molecular responses such as increase in enzyme activities and gene expression associated with oxidative stress response and phenylpropanoids biosynthesis [17]. In this study the presence of B.c-A increased PAL activity and chs gene expression, both associated with phenylpropanoids biosynthesis. Moreover, antioxidant enzymes as SOD and CAT activities were also significantly increased by B.c-A applications in tomato plants. Thus, it is clear that this bacterium induced defenseresponse in the treated tomato plants evaluated in this work. 
In vitro antagonistic activity against $\mathrm{Cmm}$ was shown by B.c-A grown on LB or MM, indicating that both media evaluated in this study did not affect the physiology of this bacterium regarding the antagonistic activity against $\mathrm{Cmm}$. This type of knowledge might be important for future industrial application purposes of B.c-A, because it is important to search for cheaper culture mediums, in order to diminish costs of large-scale production of PGPBs. Moreover, it has been reported that strains of B. subtilis and Pseudomonas sp display antagonistic activity in vitro and in vivo, respectively, against $\mathrm{Cmm}$ and the bacterial canker in tomato [24] and [25]. To our knowledge, the results of the present work are the first report showing that a strain of Bacillus cereus (as B.c-A) displays in vitro and in vivo antagonistic activity against $\mathrm{Cmm}$ and the canker disease provoked by this pathogen in tomato.

Finally, it has been shown that several PGPB's like Bacillus sp can confer disease resistance to plants through induced systemic resistance (ISR) regulated by jasmonic acid, as reported by Dejellout [26]. Actually, it has been shown that B. subtilis SL18r was able to increase the resistance of tomato plants against the invasion of $B$. cinerea in such an effective manner that did not require for activating a series of pathogenesis-related proteins and best fitted plant growth [27].

Moreover, it has also been reported that Bacillus sp as PGPB, induces systemic acquired resistance (SAR) pathway, that normally is induced by infection of virulent, avirulent, or nonpathogenic microorganisms and it is regulated by salicylic acid (SA) [28]. In the present study, B.c-A showed significant induction of biochemical and molecular markers related to induced or systemic resistance (ISR or SAR). Distinguishing ISR from SAR with a PGPB (as B.c-A) as an inductor is not obvious. Trying to analyze the pathway by which B.c-A induced the observed resistance phenotype to bacterial canker in tomato plants in the present work, the gene expression analysis of a pathogenesis-related gene as $p r-1 a$, considered as a SAR marker, displayed a repression by the B.c-A treatment (Figure 5). The latter result strongly suggested that B.c-A induced bacterial canker resistance in this study by a SA-independent pathway. In addition, B.c-A significantly induced chs gene, related to flavonoids biosynthesis. Flavonoids have been related to crop protection in several plant-microbe interaction models [3]. Thus, it is likely that at least partially, the tolerance to bacterial canker in tomato induced by B.c-A is related to phenylpropanoids, especially flavonoids production.

Based on the above-mentioned results, B.c-A might be an interesting PGPB alternative to be used as an element in the sustainable production of tomato under greenhouse conditions at least in Central Mexico.

\section{Materials and Methods}

\subsection{Media for Bacterial Cultivation}

For bacterial cultivation during the study, Luria Bertani (LB) and M-9 minimal medium (MM) was used. Only in the case of inorganic phosphate solubilization assays the Pikovskaya medium was used. Concentration of bacteria was determined in all cases by serial dilutions and expressed as $\mathrm{CFU} \mathrm{mL} \mathrm{mL}^{-1}$.

\subsection{Isolation of $P G P B$}

Root samples were collected from a castor bean plant (Ricinus communis) located at the facilities of the Autonomous University of Querétaro Amazcala campus Amazcala $\left(20^{\circ} 09^{\prime} \mathrm{N}, 46100^{\circ} 40^{\prime} \mathrm{W}\right.$ to $\left.1900 \mathrm{~m}\right)$ where the predominant climate is semi-desertic with average temperatures of $18^{\circ} \mathrm{C}$ and average rainfall of $200 \mathrm{~mm}$. Castor bean was selected for searching PGPB's based on historical observations in this plant species for biotic and abiotic tolerance for several years in campus Amazcala. One g of root was immersed in $9 \mathrm{~mL}$ of sterile saline solution and processed further for isolation of bacteria by serial dilutions up to dilution factor of $10^{-6}$ were prepared followed by spreading on for 2-3 days [2]. The isolated colonies were subcultured individually in LB agar and cryopreserved at $-80{ }^{\circ} \mathrm{C}$ in $40 \%$ glycerol for future studies. Five types of colonies were obtained and named as: RR1, 
RR2, RR3, RR4, and RR5. The RR2 isolate was the only one evaluated in the present work, based on that was observed with the highest number of colonies in the different dilutions.

\subsection{PCR Amplification of $16 S$ rRNA and Sequence Analysis}

DNA purification from the RR2 isolate was carried out by a modification of the Gilbert protocol by replacing the Tris buffer with CTAB [28]. The genomic DNA obtained was stored at $-20^{\circ} \mathrm{C}$ for analysis of the $16 \mathrm{~S}$ ribosomal gene sequence. For the amplification of the 16S gene fragment by PCR, primers $27 \mathrm{~F}$ (5'-GAGTTTGATCCTGGCTCAG-3') and 1492 R (5'-GGTTACCTTACGACTT-3') were used [29]. The reaction was carried out as follows: initial denaturation at $95{ }^{\circ} \mathrm{C}$ for $10 \mathrm{~min}, 30$ cycles at $95{ }^{\circ} \mathrm{C}$ for $30 \mathrm{~s}, 50{ }^{\circ} \mathrm{C}$ for $30 \mathrm{~s}$, and $72{ }^{\circ} \mathrm{C}$ for $45 \mathrm{~s}$ and final extension $72{ }^{\circ} \mathrm{C}$ for $5 \mathrm{~min}$. The products were separated by electrophoresis in $1.2 \%$ agarose gel and observed one band at $1500 \mathrm{bp}$. The $16 \mathrm{~S}$ DNA sequence obtained from the amplicon was compared with others in the Gen Bank database using NCBI BLAST program in http:/ / www.ncbi.n1m.nih.gov/blast/Blast.cgi (accessed on 6 February 2021). This sequence was submitted to the GenBank/EMBL/DDBJ database under the accession number MK941165.

\subsection{Detection of GA3 by HPLC}

The determination of gibberellins was made by HPLC [30]. Samples of $20 \mathrm{~mL}$ of supernatant of Luria Bertani broth in which RR2 isolate was growing for $24 \mathrm{~h}$ was collected and treated as described [30]. In these studies, uninoculated LB was used as experimental control. A solution of GA3 (Sigma-Aldrich) was used as a standard for these analyses. Quantification was performed on an Agilent 1200 series HPLC, UV-VIS 6120 Quadrupole using an Eclipse plus C18 $5 \mu \mathrm{m}$ particle size column. All analyses were carried out in triplicate.

\subsection{Inorganic Phosphate Solubilization}

The ability to solubilize inorganic phosphate was tested by depositing $5 \mu \mathrm{L}$ of the overnight growth of the isolate in Luria Bertani (LB) agar and incubation at $28^{\circ} \mathrm{C} \pm 2{ }^{\circ} \mathrm{C}$ on the center of petri dishes with Pikovskaya agar (PVK) for 10 days at $30^{\circ} \mathrm{C} \pm 2{ }^{\circ} \mathrm{C}$ [31]. A commercial strain of Bacillus subtilis (PROCOBI, Queretaro, México) was evaluated as positive control. The formation of transparent zones around the bacterial colonies was an indication of the solubilization of the inorganic phosphate contained in the PVK agar. This analysis was carried out in two independent experiments in triplicate and the solubilization was determined by measuring the diameter of the transparent zones of the solubilization halo generated in the PVK medium using a vernier [32]. The study was carried out in two independent experiments $(n=3$, total in two experiments $n=6)$.

\subsection{Effect on Plant Growth Promotion in Tomato}

The effect of B.c-A on the growth of tomato seedlings cv. "Ailsa Craig" was evaluated in a greenhouse of $150 \mathrm{~m}^{2}$. The average temperature of the greenhouse was $29{ }^{\circ} \mathrm{C} \pm 3{ }^{\circ} \mathrm{C}$ and the relative humidity $70 \%$, the photoperiod corresponded to natural light of 12:12 light-dark cycles. Plants were irrigated daily to field capacity (100 mL per day) and the nutrient solution used was Steiner [33].

B.c-A was grown in LB broth with constant agitation at $180 \mathrm{rpm}$ at $30{ }^{\circ} \mathrm{C}$ for $48 \mathrm{~h}$. At the end of the logarithmic phase, the bacterial culture was centrifuged at $300 \mathrm{rpm}$ for $3 \mathrm{~min}$ and the supernatant was discarded, the pellet was resuspended in sterile water. The aqueous suspension was diluted until it reached a concentration of $1.5 \times 10^{8} \mathrm{CFU} \mathrm{mL}^{-1}$ determined by serial dilutions. The study was carried out in two independent experiments with a randomized block design with three replications and experimental units of sixplants. The treatments consisted in the immersion of seeds during $5 \mathrm{~min}$ in sterile water (negative control) and two treatments with immersion during the same time in 2 different concentrations of B.c-A $\left(1 \times 10^{4} \mathrm{CFU} \mathrm{mL} \mathrm{mL}^{-1}\right.$ and $\left.1 \times 10^{8} \mathrm{CFU} \mathrm{mL}^{-1}\right)$. Then, $0.5 \mathrm{~mL}$ of the bacterial suspension per $\mathrm{kg}$ of substrate was inoculated at the base of the plant (a 3:1 mix 
of peat moss:vermiculite) where the tomato plants were growing. The first inoculation in the substrate was carried out when the plants generated their first true leaves (day 3) and the subsequent inoculations were weekly for 45 days post-germination. Basal stem width and plant height were measured using a vernier, as well as dry weight (differential weight of the 6 whole plants for each treatment after drying in oven at $50{ }^{\circ} \mathrm{C}$ during $24 \mathrm{~h}$ ), and amount of chlorophyll (measured as SPAD units, Minolta, Osaka, Japan) were determined.

\subsection{Antagonism Test against Clavibacter Michiganensis In Vitro}

Three different strains of $\mathrm{Cmm}$ were isolated in LB plates from diseased tomato plants in production areas affected by these bacteria in Central Mexico (Acr42, 1565 and sp) and provided by molecular biology department at IPICYT. Five hundred $\mu \mathrm{L}$ of a suspension of each Cmm isolate grown in liquid LB $\left(1 \times 10^{8} \mathrm{CFU} \mathrm{mL}{ }^{-1}\right)$, were dispersed on the surface of LB agar plates. After $5 \mathrm{~min}$, filter paper discs of $5 \mathrm{~mm}$ in diameter previously immersed in a suspension of B.c-A $\left(1 \times 10^{8} \mathrm{CFU} \mathrm{mL}{ }^{-1}\right)$ grown either on LB or MM (to evaluate the effect of bacteria grown in minimal nutrient medium) [34] were placed on the plates previously inoculated with $\mathrm{Cmm}$ [35]. The plates were incubated at $28{ }^{\circ} \mathrm{C} \pm 2{ }^{\circ} \mathrm{C}$ for $48-72 \mathrm{~h}$ or until a zone of inhibition was observed. LB was used as a negative control, and the commercial product Qbacter ${ }^{\circledR}$ (Quimcasa, Querétaro, México) as a positive control. In order to valuate possible general inhibitory effects by other bacteria, an E. coli strain $(\mathrm{DH} 5 \alpha)$ and an isolate from Central México of Pseudomonas aeruginosa were also included in the study. The inhibitory effect was determined as a straight line measured from the border of the filter paper until the border of the inhibition zone in the plates. Three independent experiments were carried out for these assays with three replicates.

\subsection{Evaluation of Antagonistic Activity of B.c-A against Clavibacter Michiganensis under Greenhouse Conditions}

The antagonistic effects under greenhouse were carried out in two independent experiments. The surface of the greenhouse was $15 \mathrm{~m}^{2}$, with average temperature of $29^{\circ} \mathrm{C} \pm 3{ }^{\circ} \mathrm{C}$ and relative humidity $80 \%$ and a natural light photoperiod of $12 \mathrm{~h}: 12 \mathrm{~h}$ (lightdark). Thirty-one days post-germination tomato plants were inoculated with B.c-A by both spraying onto leaves and applying in the substrate $1 \mathrm{~mL}$ per $\mathrm{kg}$ of substrate of an inoculum grown in $\mathrm{MM}\left(1 \times 10^{8} \mathrm{CFU} \mathrm{mL}^{-1}\right)$ in three weekly applications. Two days later, the first B.c-A application, the most pathogenic Cmm strain (AcR42) was inoculated by puncturing the stem with a bacterial suspension grown in liquid $\mathrm{LB}\left(1 \times 10^{8} \mathrm{CFU} \mathrm{mL}{ }^{-1}\right)$. As chemical control, Terra- $\mathrm{Cu}^{\circledR}$ product (CYR-agroquimica company, Morelos, México) was applied according to manufacturer instructions $(50 \mathrm{~mL}$ per plant in the substrate at a concentration of $140 \mathrm{ppm})$. Meanwhile, another chemical control was the product Oxymeth $^{\circledR}$ (cuprous oxide, Cuprosa, Jalisco, Mexico) which was sprayed $(3.8 \mathrm{~mL})$ to the leaves in a concentration of $0.03 \mathrm{~g} \mathrm{~mL}^{-1}$ when the first symptoms of disease appeared. As a negative control, plants with no pathogen inoculation were used. The experimental set up of the two independent experiments consisted in a completely randomized design, using 9 plants (sowed in pots of $450 \mathrm{~cm}^{3}$ using peat moss as substrate, Hydro Environment, México City, México) as experimental unit. The variables measured were plant height (with a rule) and the severity of bacterial canker disease using the Soylu scale at 30 and 45 days post-germination [36].

\subsection{Stress Response-Antioxidant Enzyme CAT, PAL, SOD Activities Measurements}

Total soluble proteins (TSP) were extracted from lyophilized leaves (50 mg) ground with $1.5 \mathrm{~mL}$ extraction buffer containing $0.05 \mathrm{M}$ phosphate buffer ( $\mathrm{pH} 7.8$ ), $0.1 \mathrm{mM}$ Na2EDTA. The samples were centrifuged at $12,000 \mathrm{rpm}$ for $15 \mathrm{~min}$ at $4{ }^{\circ} \mathrm{C}$. Protein concentration was determined using the Bradford Reagent (Merck, Darmstadt, Germany) and bovine serum albumin (Merck, Darmstadt, Germany) as standard. The supernatant obtained for the TSP assay was used to quantify catalase (CAT), phenylalanine ammonia lyase (PAL) and superoxide dismutase (SOD) activities. CAT activity was assayed by following the initial rate of $\mathrm{H}_{2} \mathrm{O}_{2}$ degradation for $120 \mathrm{~s}$ monitored at $240 \mathrm{~nm}$, Enzyme activity was 
determined [37] with some modifications. PAL was determined by spectrophotometry at $290 \mathrm{~nm}$ quantifying the cinnamic acid formed from the catalysis of L-phenylalanine [38]. SOD activity was determined spectrophotometry at $560 \mathrm{~nm}$ by measuring the photochemical reduction of nitroblue tetrazolium (NBT) [39].

\subsection{Gene Expression-Associated with Plant Defense}

Molecular markers for phenylpropanoids biosynthesis (chalcone synthase, chs, accession number NM_001247104.2) and a molecular marker of salicylic acid plant defense pathway (pathogenesis-related protein 1a, pr-1a, accession number XM_004242627.4) were evaluated in the study as indicators of immunity induction in the tomato plants. The actin gene (act, accession number AB199316.1) was used as housekeeping control. Triplicate upper leaf samples were ground in liquid nitrogen, and RNA extracted (PureZOL ${ }^{\mathrm{TM}}$ RNA Isolation, Bio-Rad). The integrity of the extracted RNA was checked on agarose gel electrophoresis, and its purity and concentration were assessed by a NanoDrop. One $\mu \mathrm{g}$ of total RNA of high purity $(260 / 280 \mathrm{~nm}$ absorbance ratio above 2.0 and $260 / 230 \mathrm{~nm}$ absorbance ratio 1.8-2.0) was used to synthesize cDNA following the manufacturer instructions (Thermo Fisher ${ }^{\mathrm{TM}}$ ). The cDNA was diluted to $400 \mathrm{ng} \mathrm{uL} \mathrm{u}^{-1}$ and stored in $-20{ }^{\circ} \mathrm{C}$ for qPCR until further analysis. Primer sequences used to amplify pr-1a (forward $5^{\prime}$ GCCAAGCTATAACTACGCTACCAAC-3' ; reverse: 5' - GCAAGAAATGAACCACCATCC$3^{\prime}$ ), chs (forward 5'-CCAAGGACTTGGCTGAGAAC-3'; reverse 5'-TATCGGGGACAAGAGTTTGG-3') and actine (act) as housekeeping control gene (forward $5^{\prime}$-ATGTGACGTGGATATTAGGAAAG-3'; reverse: 5'-AGGGAAGCCAAGATAGAGCC-3') were used. The qPCR analysis was carried out in a real Time System (BIORAD Laboratories) using sybrgreen as fluorophore. Reaction conditions for all the genes were: $5 \mathrm{~s}$ at $94{ }^{\circ} \mathrm{C}$ and 40 cycles of $5 \mathrm{~s}$ at $94{ }^{\circ} \mathrm{C}$ and $30 \mathrm{~s}$ at $57^{\circ} \mathrm{C}$. The relative gene expression levels were calculated using the $\Delta \Delta \mathrm{Ct}$ method [40].

\subsection{Statistical Analysis}

For all the experiments, a normality test of data (Anderson-Darling test, $p=0.05$ ) was carried out. If data were not in the normality, non-parametric tests as Kruskal-Wallis H test $(p=0.05)$ was carried out instead of one-way ANOVA $(p=0.05)$. All the results obtained were expressed by the means plus/minus their standard errors. The differences between treatments were determined by one-way ANOVA, and differences between the means were determined by Tukey test $(p=0.05)$ using the GraphPad PRISM version 7 software. Only in antagonistic tests in greenhouse for $\mathrm{Cmm}$ severity data (as ordinal variable and out of normality), the statistical analysis was carried out using the Kruskal-Wallis H test (XLSTAT-Excel) and the Dunn's tests $(p=0.05)$ to determine differences between treatments.

\subsection{Ethical Statement}

The authors declare that they have no conflict of interest. This manuscript does not contain any studies with human or animal participants performed by any of the authors, and this project was approved by ethics committee from School of Engineering from Autonomous University of Querétaro (Queretaro, Mexico) with approval reference number CEAIFI-100-2018-TP.

Author Contributions: Conceptualization, R.G.G.-G. and R.V.O.-V.; methodology, N.S.-A., J.A.V.-H. and E.M.E.-S.; statistical analysis, I.T.-P.; validation, Á.G.A.-S., E.R.-G. and A.L.R.-G.; formal analysis, R.G.G.-G.; investigation, N.S.-A. and J.A.V.-H.; resources, R.G.G.-G.; data curation, I.T.-P.; writingoriginal draft preparation, R.G.G.-G. and N.S.-A.; writing-review and editing, R.G.G.-G., N.S.-A. and Á.G.A.-S.; project administration, R.G.G.-G.; funding acquisition, R.G.G.-G. and N.S.-A. All authors have read and agreed to the published version of the manuscript.

Funding: This research was partial support by SEP-CONACYT 2016 (283259) to RGGG and Fondo para el desarrollo del conocimiento (FONDEC-UAQ-2019) to N.S.-A. and R.G.G.-G. N.S.-A. and J.A.V.-H. also acknowledges to Consejo Nacional de Ciencia y Tecnología and Universidad Autónoma de Querétaro for postgraduate studies grant support. 
Data Availability Statement: The data of 16S ribosomal gene sequence of Bacillus cereus Amazcala is located in the following link: https:/ / www.ncbi.nlm.nih.gov/nuccore/1654038701 (accessed on 6 February 2021).

Acknowledgments: Authors acknowledges to "Facultad de Ingeniería, Campus Amazcala, Universidad Autónoma de Querétaro" for all the facilities to develop this project.

Conflicts of Interest: The authors declare no conflict of interest and the funders had no role in the design of the study; in the collection, analyses, or interpretation of data; in the writing of the manuscript, or in the decision to publish the results.

\section{References}

1. Silva, G.; Ursi, M.; Prezotto, R.; Alves, T.; Garcia, P.; Tatsuya, T.; Seiko, V.; Gomes, T.; Martinez, A.L.; Teruhico, F. Plant-promoting rhizobacteria Methylobacterium komagatae increases crambe yield, roots system and height. Ind. Crop. Prod. 2018, 121, $277-281$. [CrossRef]

2. Haiyambo, D.H.; Chimwwamurombe, P.M.; Reinhold-Hurek, B. Isolation and screening of rhizosphere bacteria from grasses in East Kavango region of Namibia for plant promoting characteristics. Curr. Microbiol. 2015, 71, 566-571. [CrossRef]

3. Kumar, A.; Verma, J.P. Does plant microbe interaction confer stress tolerance in plants: A review. Microbiol. Res. 2018, $207,41-52$. [CrossRef] [PubMed]

4. Santos, M.; Nogueira, M.A.; Hungria, M. Microbial inoculants: Reviewing the past, discussing the present and previewing an outstanding future for the use of beneficial bacteria in agriculture. AMB Exp. 2019, 9, 205. [CrossRef]

5. Alavi, P.; Starcher, M.R.; Zachow, C.; Müller, H.; Berg, G. Root-microbe systems: The effect and mode of interaction of Stress Protecting agent (SPA) Stenotrophomonas rhizophila DSM14405(T). Front. Plant Sci. 2013, 4, 141. [CrossRef]

6. Ruzzi, M.; Aroca, R. Plant growth-promoting rhizobacteria act as biostimulants in horticulture. Sci. Hort. 2015, 196, 124-134. [CrossRef]

7. Tiwari, S.; Prasad, V.; Chauhan, P.S.; Lata, C. Tiwari, Bacillus amyloliquefaciens confers tolerance to varios abiotic stresses and modulates plant response to phytohormones through osmoprotection and gene expression regulation in rice. Front. Plant Sci. 2017, 29, 1510. [CrossRef] [PubMed]

8. Berger, B.; Baldermann, S.; Ruppel, S. The plant growth-promoting bacteria Kosakonia radicincitans improves fruit yield and quality of Solanum lycopersicum. J. Sci. Food Agric. 2017, 14, 4865-4871. [CrossRef] [PubMed]

9. Calvo-Polanco, M.; Sánchez-Romera, B.; Aroca, R.; Asins, M.J.; Declerck, S.; Dodd, I.D.; Martínez-Andújar, C.; Albacete, A.; Riuz-Lozano, J.M. Exploring the use of recombinant inbred lines in combination with benefial microbial inoculants to improve drought stress tolerance in tomato. Environ. Exp. Bot. 2016, 131, 47-57. [CrossRef]

10. SAGARPA. Aumenta 35 por Ciento Producción de Jitomate "Hecho en México", CDMX: SAGARPA. Available online: https:/ / www.gob.mx/agricultura\%7Caguascalientes/articulos/aumenta-35-por-ciento-produccion-de-jitomate-hecho-enmexico-141530\#: \{\}:text=De\%20acuerdo\%20con\%20estad\%C3\%ADsticas\%20de,dos\%20millones\%20769\%20mil\%20toneladas (accessed on 8 May 2017).

11. Lanteigne, C.; Gadkar, V.J.; Wallon, T.; Novinscak, A.; Filion, M. Production of DAPG and HCN by Pseudomonas sp. LBUM300 contributes to the biological control of bacterial canker of tomato. Phytopathology 2012, 10, 967-973. [CrossRef] [PubMed]

12. Nandi, M.; Macdonald, J.; Liu, P.; Weselowski, B.; Yuan, Z. Clavibacter michiganensis ssp. michiganensis: Bacterial canker of tomato, molecular interactions, and disease management. Mol. Plant Pathol. 2019, 19, 2036-2050. [CrossRef]

13. Chalupowicz, L.; Barash, I.; Reuven, M.; Dror, O.; Sharabani, G.; Gartemann, K.-H.; Eichenlaub, B.; Sessa, G.; Manulis-Sasson, S. Differential contribution of Clavibacter michiganensis ssp. michiganensis virulence factors to systemic and local infection in tomato. Mol. Plant Pathol. 2017, 18, 336-346. [CrossRef] [PubMed]

14. Abo-Elyousr, K.A.M.; Khalil, H.M.M.; Hashem, M.; Alamri, S.A.M.; Mostafa, Y. Biological control of the tomato wilt caused by Clavibacter michiganensis subsp. Michiganensis using formulated plant growth-promoting bacteria. Egypt J. Biol. Pest. Control 2019, 29, 54. [CrossRef]

15. de León, L.; Siverio, F.; López, M.M.; Rodríguez, A. Comparative efficiency of chemical compounds for in vitro and in vivo activity against Clavibacter michiganensis subsp. michiganensis, the causal agent of tomato bacterial canker. Crop Prot. 2008, 27, 1277-1283. [CrossRef]

16. Vazquez-Hernandez, M.C.; Parola-Contreras, I.; Montoya-Gómez, L.M.; Torres-Pacheco, I.; Schwartz, D.; Guevara-González, R.G. Eustressors: Chemical and physical stress factors used to enhance vegetables production. Sci. Hortic. 2019, 250, $223-229$. [CrossRef]

17. García, R.A.; Lovaisa, N.C.; Ulla, E.L. Isolation and characterization of phosphate solubilizing bacteria in northwestern Argentina and its effect in promoting growth in maize (Zea mays L.). Rev. Agron. Noreste Argent. 2015, 35, 19-28.

18. Saeid, A.; Prochownik, E.; Dobrowolska-Iwanek, J. Phosphorus Solubilization by Bacillus species. Molecules $2018,23,2897$. [CrossRef]

19. Gil-Jae, J.; Young-Mong, K.; In-Jung, L.; Kyung-Sik, S.; In-Koo, R. Growth promotion of red pepper plug seedings and the production of gibberellins by Bacillus cereus, Bacillus acroides and Bacillus pumilus. Biotechnology 2004, 26, 487-491. [CrossRef] 
20. Bashan, Y.; Kamnev, A.; de-Bashan, L.E. Tricalcium phosphate is inappropriate as a universal selection factor for isolating and testing phosphate-solubilizing bacteria that enhance plant growth: A proposal for an alternative procedure. Biol. Fertile Soils 2013, 49, 465-479. [CrossRef]

21. Kumar, A.; Bahadur, I.; Maurya, B.R.; Raghuwanshi, R.; Meena, V.S.; Singh, S.; Dixit, J. Does a plant growth-promoting rhizobacteria enhance agricultural sustainability. J. Pure Appl. Microbiol. 2015, 9, 15-724.

22. Grobelak, A.; Napora, A.; Kaacprzak, M. Using plant growth-promoting rhizobacteria (PGPR) to improve plant growth. Ecol. Eng. 2015, 84, 22-28. [CrossRef]

23. Takishita, Y.; Jean-Benoit, C.; Smith, D.L. Biocontrol rhizobacterium Pseudomonas sp. 23 S induces systemic resistance in tomato (Solanum lycopersicum L.) against bacterial canker Clavibacter michiganensis subsp. michiganensis. Front. Microbiol. 2018, 9, 2119. [CrossRef]

24. Milijasevic-Marcic, S.; Todorovic, V.; Stanojevic, O.; Beric, T.; Stankovic, S.; Todorovic, B.; Potocnik, I. Antagonistic potential of Bacillus spp. isolates against bacterial pathogens of tomato and fungal pathogen of pepper. Pestic. Phytomed. 2018, 33, 9-18. [CrossRef]

25. Djellout, H.; Raio, A.; Boutoumi, H.; Kirimi, Z. Bacillus and Pseudomonas spp. Strains introduce a response in phenolic profile and enhance biosynthesis of antioxidant enzymes in Agrobacterium tumefaciens infected tomato plants. Eur. J. Plant Pathol. 2020, 157, 269-280. [CrossRef]

26. Zhou, C.; Zhu, J.; Qian, N.; Gou, J.; Yan, C. Bacillus subtilis SL18r induces tomato resistance against Botrytis cinerea, involving activation of long non-coding RNA, MSTRG18363, to decoy miR1918. Front. Plant Sci. 2021, 11, 634819. [CrossRef]

27. Kim, J.-S.; Lee, J.; Lee, C.-H.; Woo, S.Y.; Kang, H.; Seo, S.-G.; Kim, S.-H. Activation of pathogenesis-related genes by the Rhizobacterium, Bacillus sp. JS, which induces systemic resistance in tobacco plants. Plant Pathol. J. 2015, 31, 195-201. [CrossRef]

28. Gilbert, J.A. High-throughput next generation sequencing. In Methods in Molecular Biology (Methods and Protocols); Springer: Berlin/Heidelberg, Germany, 2011; Volume 733, pp. 173-183. [CrossRef]

29. Khati, P.; Sharma, A.; Gangola, S.; Kumar, R.; Bhatt, P.; Kumar, G. Impact of agri-usable nanocompounds on soil microbial activity: An indicator of soil health. CLEAN Soil Air Water 2017, 45. [CrossRef]

30. Escamilla-Silva, E.; Dendooven, L.; Uscanga, J.A.; Monroy, A.I.; González-Alatorre, G.; de la Torre, M. Morphological development and gibberellin production by different strains of Gibberella fujikuroi in shake flasks and bioreactor. World J. Microbiol. Biotechnol. 1999, 15, 753-755. [CrossRef]

31. Grönemeyer, J.L.; Burbano, C.S.; Hurek, T.; Reinhold-Hurek, B. Isolation and characterization of root associated bacteria from agricultural crops in the Kavango region of Namibia. Plant Soil 2012, 356, 67-82. [CrossRef]

32. Premono, M.E.; Moawad, A.M.; Vlek, P.L.G. Effect of phosphate solubilizing Pseudomonas putida on the growth of maize and its survival in the rhizosphere. Indones J. Crop. Sci. 1996, 11, 13-23.

33. De la Rosa-Rodríguez, R.; Lara-Herrera, A.; Padilla-Bernal, L.E.; Avelar-Mejía, J.J.; España-Luna, M.P. Proportion of drainage of the nutritive solution in the yield and quality of tomato in hydroponics. Mex. J. Agric. Sci. 2018, 20, 4343-4353.

34. Elbing, K.; Brent, R. Media Preparation and Bacteriological Tools. Current Protocols in Molecular Biology. JWS 2002, 59, 60-65. [CrossRef]

35. Sharifazizi, M.; Harighi, B. Evaluation of biological control of Erwina Amylovora, causal agent of fire blight of pear by antagonistic bacteria. Biol. Control 2017, 104, 28-34. [CrossRef]

36. Soylu, S.; Baysal, O.; Soylu, E.M. Induction of disease resistance by the plant activator, acibenzolar s metyl, against bacterial canker (Clavibacter michiganensis subsp. michiganensis) in tomato seedings. Plant Sci. 2003, 165, 1069-1075. [CrossRef]

37. Afiyanti, M.; Chen, H.J. Catalase activity is modulated by calcium and calmodulin in detached mature leaves of sweet potato. J. Plant Physiol. 2014, 171, 35-47. [CrossRef] [PubMed]

38. Toscano, S.; Ferrante, A.; Leonardi, C.; Romano, D. PAL activities in asparagus spears during storage after ammonium sulfate treatments. Postharvest Biol. Technol. 2018, 140, 34-41. [CrossRef]

39. Hayat, S.; Ahmad, H.; Muhammad, A.; Ren, R.; Chemg, Z. Aqueous garlic extract stimulates growth and antioxidant enzymes activity of tomato (Solanum lycopersicum). Sci. Hortic. 2018, 240, 139-146. [CrossRef]

40. Livak, K.J.; Schmittgen, T.D. Analysis of relative gene expression data using real-time quantitative PCR and the 2- $\Delta \Delta C T$ method. Methods 2001, 25, 402-408. [CrossRef] 